\title{
ASSESSMENT OF THE QUALITY OF RAW MILK PURCHASED DEPENDING ON THE PRODUCTION SCALE
}

\section{OCENA JAKOŚCI SKUPOWANEGO MLEKA SUROWEGO W ZALEŻNOŚCI OD WIELKOŚCI PRODUKCJI}

\author{
Department of Ruminant Science, West Pomeranian University of Technology, Szczecin, Poland
}

\begin{abstract}
Streszczenie. Celem prowadzonych badań była ocena jakości mleka surowego skupowanego przez zakład mleczarski, z uwzględnieniem wielkości skupu, jakości mleka surowego oraz sezonowości jego skupu. Gospodarstwa podzielono na grupy ze względu na ilość produkowanego mleka: 1 grupa - do $5000 \mathrm{~kg}$ mleka miesięcznie, 2 grupa - 5001-10 $000 \mathrm{~kg}$, 3 grupa - 10001-15 $000 \mathrm{~kg}, 4$ grupa - ponad $15000 \mathrm{~kg}$. Stwierdzono nieco większą procentową zawartość tłuszczu w mleku z grupy 4. Czystość mikrobiologiczna mleka była zbliżona we wszystkich grupach, przy czym podkreślić należy małą LKS i OLB. Stwierdzono nadal istniejącą sezonowość produkcji. Wielkość produkcji w okresie żywienia letniego była większa o około 18\%. Celowa wydaje się dalsza specjalizacja gospodarstw i przejście w większych gospodarstwach na całoroczny system żywienia paszami konserwowanymi (TMR).
\end{abstract}

Key words: raw milk production, composition and quality, seasonality of production.

Słowa kluczowe: wielkość produkcji mleka surowego, skład i jakość, sezonowość produkcji.

\section{INTRODUCTION}

The suitability of milk for consumption and processing is primarily determined by its hygienic quality, which is an indication of the conditions prevailing in the producer's farm. Main importance is attributed to the hygienic conditions in which animals stay, the conditions for obtaining and storing milk and the health of cows. This problem was dealt with by many authors including Simianer et al. (1991), Smith (2003), Stanek et al. (2004), Skrzypek et al. (2006), Sharma et al. (2011), Bortacki et al. (2016). In Poland, over the last several years, milk yield and quality systematically increased. This was due to the introduction of new technologies of feeding, maintenance, raw material harvesting and distribution (Pieróg et al. 2001; Jurczak et al. 2003; Przysucha et al. 2003). The major problem was the seasonality of production and purchase of milk, which often exceeded 2: 1 quantities of milk produced during the summer months compared to winter (Wójcik et al.1997; Wójcik et al.1998; Barłowska and Litwińczuk 2003).

Corresponding author - Adres do korespondencji: Jerzy Wójcik, Department of Ruminant Science, West Pomeranian University of Technology, Szczecin, Doktora Judyma 10, 71-460 Szczecin, Poland, email: jerzy.wojcik@zut.edu.pl 
The purpose of the study was to analyze the quality of raw milk purchased by the dairy plant, taking into account the volume of purchase from individual suppliers.

\section{MATERIAL AND METHODS}

The research was carried out on the basis of data on the purchase volume and the milk assessment obtained from the documentation of the laboratory of the Dairy Plant (distribution center) in Pyrzyce belonging to the MLEKOVITA Capital Group. Data on monthly delivery, percentage of fat and protein, total number of bacteria and number of somatic cells were collected for the period 1.01.2013 to 31.12. Suppliers are divided into four groups according to the quantity of milk supplied: 1 group to $5000 \mathrm{~kg}$ of milk per month; 2 groups $5001-10000 \mathrm{~kg}$ of milk; 3 groups of 10001 to 15000 milk per month; 4 group over $15000 \mathrm{~kg}$ of milk per month.

The significance of the differences in the parameters compared between the producer groups was determined by means of one-way analysis of variance in the non-ortogeneic system, while the significance of differences in the mean number of somatic and bacterial cells was determined using the Kruskal-Wallis test using the Statistica program.

\section{RESULTS AND DISCUSSION}

In the individual groups of producers, the following average deliveries were achieved: in $1-3966 \mathrm{~kg}$ ( $\mathrm{v} 43.86 \%)$, in $2-5868 \mathrm{~kg}$ ( $\mathrm{v} 32.68 \%)$, in $3-12122 \mathrm{~kg}$ ( $\mathrm{v} 25.49 \%)$ and in $4-19392$ ( $v$ 65.54\%). The assessed producer groups were dominated by smaller producers with relatively large variations in supply within the groups, while the greatest variability was found in the largest production group of which we can say that they were specialized farms.

In Table 1 and on Fig. 1 and Fig. 2 one presented the average percentage of fat and protein in milk from different groups of suppliers, and the content of these components in particular months of the year. The mean percentage of fat in milk was quite large in all groups, but significantly ( $p \leq 0.05$ ) higher in the group of the largest producers. This could have been due to a greater number of manufacturers feeding the herds with modern systems (TMRs). According to Gawlik (2010), cow's consumption of a larger structural bulk feed with higher energy concentration results in an increase in the fat content in milk. In individual months, the percentage of fat was also predominantly higher in group 4 . It was also found that the fat content decreased in the summer months, which was probably caused by pasture feeding, especially in smaller production groups. The average percentage of protein increased with production. One found significantly $(p \leq 0.05)$ higher protein content in milk from group 4 producers compared to other groups and significantly higher $(p \leq 0.05)$ in group 3 compared to groups 2 and 4. According to Lipiński (2008) and Radkowska (2013), the protein content of milk is primarily determined by the energy content of the feed, which can be increased by increasing the proportion of solid feed, the use of very high quality basic feed and various feed additives. The percentage of protein decreased slightly in the first months of the pasture season (May, June) and then gradually increased in all groups. 
Table 1. Percentage of fat and protein in milk

Tabela 1. Procentowa zawartość tłuszczu i białka w mleku

\begin{tabular}{lccccccc}
\hline \multirow{2}{*}{$\begin{array}{c}\text { Group } \\
\text { Grupa }\end{array}$} & $\begin{array}{c}\text { Number of } \\
\text { milk suppliers } \\
\text { Liczba } \\
\text { dostawców } \\
(\mathrm{n})\end{array}$ & $\bar{x}$ & $\mathrm{~s}$ & $\mathrm{~F}$ & & $\bar{x}$ & $\mathrm{~s}$ Protein - Białko [\%] \\
\hline 1 & 60 & $3.90^{\mathrm{a}}$ & 0.17 & 4.36 & 3.24 & 0.12 & $\mathrm{v}$ \\
\hline 2 & 60 & $3.90^{\mathrm{a}}$ & 0.18 & 4.61 & 3.26 & 0.08 & 2.45 \\
\hline 3 & 60 & $3.88^{\mathrm{a}}$ & 0.17 & 4.38 & 3.30 & 0.07 & 2.12 \\
\hline 4 & 36 & $3.98^{\mathrm{b}}$ & 0.18 & 4.52 & 3.35 & 0.06 & 1.79 \\
\hline Total & 216 & 3.91 & 0.18 & 4.60 & 3.28 & 0.09 & 2.90 \\
\hline
\end{tabular}

$a, b$ - statistically significant differences at $p \leq 0.05$ - różnice istotne na poziomie $p \leq 0,05$.

[\%]

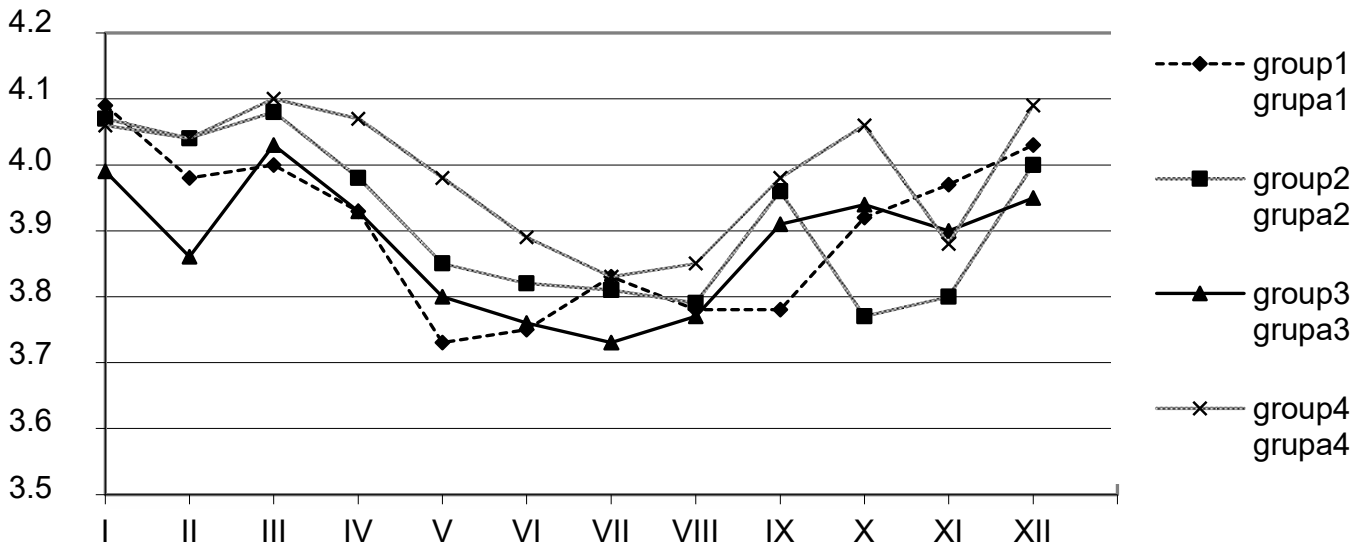

Fig.1. Average percentage of fat in milk in particular months of the year

Rys.1. Średnia procentowa zawartość tłuszczu w mleku w poszczególnych miesiącach roku

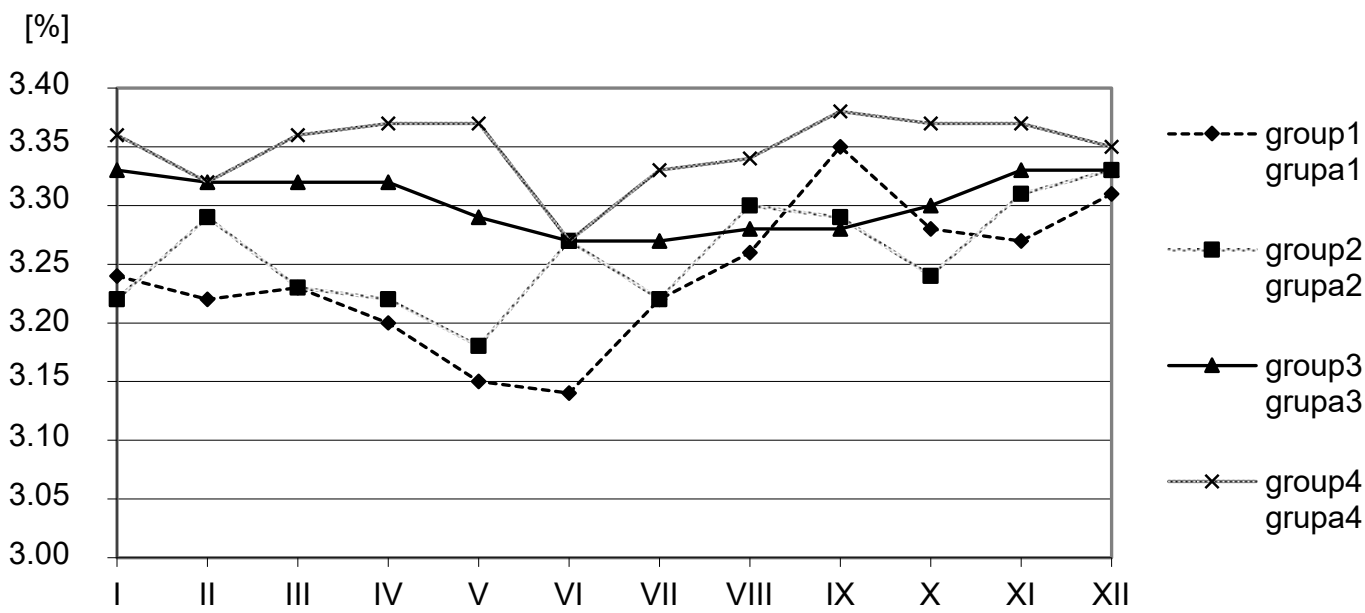

Fig. 2. Average percentage of protein in milk in particular months of the year

Ryc. 2. Średnia procentowa zawartość białka w mleku w poszczególnych miesiącach roku 
Table 2 and Fig. 3 show the development of the average number of somatic and bacterial cells and the number of somatic cells in each month of the year in milk from individual groups of suppliers. The number of somatic and bacterial cells was equalized and satisfactory in all groups, which is a testimony to the good microbiological quality of the milk produced. In particular months of the year, the number of somatic cells was also fairly even, with a slight increase in summer months, with the exception of group 4. Cellular decline was observed in the autumn months. Brzozowski et al. (1999) report that SCC in the summer months is usually higher than in other seasons. Pilarska (2014), however, found significant differences in the number of SCC between the winter and summer seasons, depending on the assessment year. The number of TBC was generally satisfactory and very level in milk from suppliers of different production scales. Kobus and Kmiecik (2006) reported higher bacterial counts and a small percentage of milk fat (up to $3000 \mathrm{~kg}$ ) per month compared to large producers (over $100,000 \mathrm{~kg}$ of milk).

Table 2. Average SCC and TBC in individual supplier groups

Tabela 2. Średnia SCC i TBC w poszczególnych grupach dostawców

\begin{tabular}{lccccccc}
\hline \multirow{2}{*}{$\begin{array}{l}\text { Group } \\
\text { Grupa }\end{array}$} & $\begin{array}{c}\text { Number of } \\
\text { milk suppliers } \\
\text { Liczba } \\
\text { dostawców }\end{array}$ & $\bar{x}$ & $\mathrm{~s}$ & $\mathrm{v}[\%]$ & $\bar{x}$ & $\mathrm{~s}$ & $\mathrm{~V}$ [\%] \\
\cline { 2 - 8 } & 60 & 195 & 49 & 25.12 & 78 & 5.49 & 7.04 \\
\hline 1 & 60 & 230 & 40 & 17.39 & 79 & 5.65 & 7.15 \\
\hline 3 & 60 & 199 & 37 & 18.59 & 78 & 6.50 & 8.33 \\
\hline 4 & 36 & 229 & 70 & 30.57 & 77 & 15.48 & 20.10 \\
\hline $\begin{array}{l}\text { Total } \\
\text { ogółem }\end{array}$ & 216 & 211 & 50 & 23.70 & 78 & 8.25 & 10.58 \\
\hline
\end{tabular}

SCC - Somatic Cell Counts (thousands of cells) - liczba komórek somatycznych (w tys.), TBC - Total Bacteria Counts - ogólna liczba bakterii.

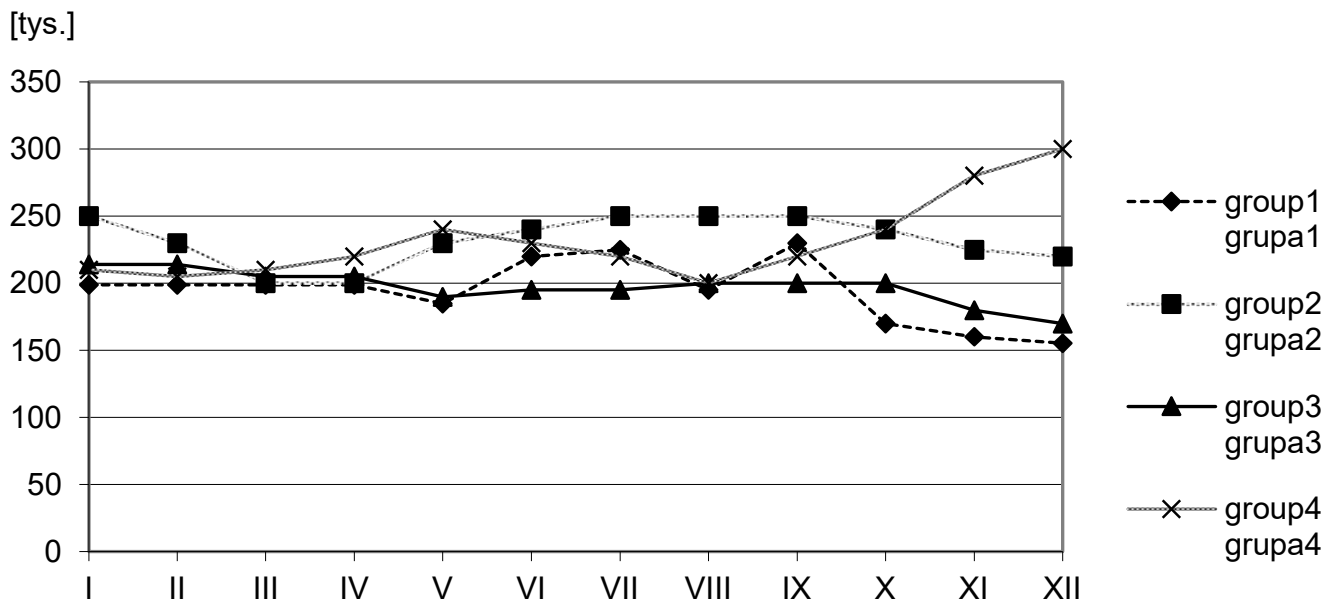

Fig. 3. Average number of somatic cells (in thousands) in particular groups of suppliers, including months Ryc. 3. Średnia liczba komórek somatycznych w mleku w poszczególnych grupach dostawców, z uwzględnieniem miesięcy 
Table 3 shows the production and composition of milk during summer and winter feeding periods. The production volume during the summer period was higher (by about 18\%), which indicates that the seasonality of production still exists. The situation has improved because, according to Wójcik et al. $(1997,1998)$, the amount of milk bought in the summer was more than double that of the winter feeding period. The reason for this situation may be the inferior quality of preserved feeds produced by traditional methods in smaller farms. The improvement was mainly due to the improvement of the quality of feeds preserved especially in larger farms (TMR feeding), which ensures good alignment and rhythm of production throughout the year. As expected, a slightly higher percentage of fat and protein was in the wintertime, while the number of somatic and bacterial cells was similar, indicating good hygiene in obtaining, storing and transporting milk to the dairy plant.

Table 3. Production volume and composition of milk during summer and winter feeding periods Tabela 3. Wielkość produkcji oraz skład mleka w okresach żywienia letniego oraz zimowego

\begin{tabular}{lccccc}
\hline \multicolumn{1}{c}{$\begin{array}{c}\text { Period } \\
\text { Okres }\end{array}$} & $\begin{array}{c}\text { Milk } \\
\text { llość mleka } \\
{[\mathrm{kg}]}\end{array}$ & $\begin{array}{c}\text { Fat content } \\
\text { in milk } \\
\text { Zawartość } \\
\text { tłuszczu } \\
\text { w mleku [\%] }\end{array}$ & $\begin{array}{c}\text { Protein content } \\
\text { in milk } \\
\text { Zawartość białka } \\
\text { w mleku [\%] }\end{array}$ & $\begin{array}{c}\text { SCC } \\
\text { [thous. - tys.] }\end{array}$ & $\begin{array}{c}\text { TBC } \\
\text { [thous. }- \text { tys.] }\end{array}$ \\
\hline $\begin{array}{l}\text { Grazing season } \\
\begin{array}{l}\text { Pastwiskowy } \\
\text { (V-IX) }\end{array}\end{array}$ & 10400 & $\begin{array}{c}3.82 \\
\text { SD } 0.15\end{array}$ & $\begin{array}{c}3.26 \\
\text { SD 0.09 }\end{array}$ & SD 51.63 & SD 9.96 \\
\hline $\begin{array}{l}\text { Winter period } \\
\text { Oborowy } \\
(\text { X-IV) }\end{array}$ & 8568 & $\begin{array}{c}3.97 \\
\text { SD 0.16 }\end{array}$ & $\begin{array}{c}3.29 \\
\text { SD 0.1 }\end{array}$ & SD 49.52 & SD 6.64 \\
\hline
\end{tabular}

SD - standard deviation - odchylenie standardowe.

Other explanations see Table 2 - Pozostałe objaśnienia zob. tab. 2.

\section{CONCLUSIONS}

The percentage of fat and protein was fairly even in all groups, but slightly higher in the milk supplied by suppliers from the fourth group (sales above $15.000 \mathrm{~kg}$ per month). This was probably due to a greater share of modern feeding systems (TMRs). The microbiological purity of milk was similar in all groups, highlighting the small LKS and OLB, which shows the good health of cows and proper milking hygiene. The number of somatic cells and the overall number of bacteria was well below the limit of the extra class. The seasonality of production has been observed. In pasture seasons, average deliveries were 18\% (1832 kg) higher than during winter feeding. It seems appropriate to continue to specialize farms and introduce in more productive flocks a perennial preserved feed feeding system (TMR).

\section{REFERENCES}

Barłowska J., Litwińczuk Z. 2003. Sezonowość produkcji i jakości mleka towarowego w regionie środkowowschodniej Polski [Seasonality of production and quality commercial milk in the east - central region of Poland]. Prz.Hod. 4, 1-4. [in Polish]

Bortacki P., Kujawiak R., Czerniawska-Piątkowska E., Wójcik J., Grzesiak W. 2016. Influence of the age on the day of first calving and the length of calving intervals on the milk yield of cows. Folia Pomer. Univ. Technol. Stetin., Agric., Aliment., Pisc., Zootech. 325(37)1, 5-12. 
Brzozowski P., Ludwiczak K., Zdziarski K. 1999. Liczba komórek somatycznych w mleku krów objętych oceną użytkowości mlecznej w Polsce Centralnej [Somatic cell count in milk from cows cocered with milk recording system in central region of Poland]. Zesz. Nauk. Prz. Hod. 44. 83-90. [in Polish]

Gawlik J. 2010. Wpływ żywienia na ilość i skład udojonego mleka [The influence of feeding on quantity and composition of milking milk]. Lub. Aktual. Rol. 9, 148. [in Polish]

Jurczak M.E., Zdziarski K. 2003. Analiza wielkości dostaw mleka z gospodarstw indywidualnych w Polsce centralnej [Analysis of volume of milk delivery from individual farms in Central Poland]. Anim. Sci. SGGW 39, Suppl. 138-144. [in Polish]

Kobus J., Kmiecik D. 2006. Jakość mikrobiologiczna i skład chemiczny mleka surowego pochodzącego z wielkich i małych gospodarstw rolnych Wielkopolski w 2004 roku [Microbiological quality and chemical composition of raw milk from big and small farms in the Wielkopolska region in 2004]. Żyw. Nauka Technol. Jakość 2(47), Suppl., 108-115. [in Polish]

Minakowski D., Lipiński K. 2008. Produkcja mleka wysokiej jakości NON STOP [Production of high quality milk NON STOP]. Hod. Bydła 9, 56-62. [in Polish]

Pieróg M., Litwińczuk A., Barłowska J. 2001. Zmiany jakości mleka towarowego w zależności od systemu odbioru i sezonu produkcji [The changes in commercial milk quality, depending on the system of milk receipt and season of production]. Zesz. Nauk. Przl. Hod. 59. 189-196. [in Polish]

Pilarska M. 2014. Wpływ pory roku i kolejnej laktacji na wydajność krów i parametry fizykochemiczne mleka [Effect of season of the year and numer of lactation on performance of cows and physiochemical parameters of their milk]. Wiad. Zootech. 52(2), 3-12. [in Polish]

Przysucha T., Grodzki H., Zdziarski K., Trzaska M. 2003.Wpływ systemu skupu, wielkości i sezonu dostawy na ogólną liczbę bakterii w mleku surowym zakwalifikowanym do najwyższych klas jakościowych [The relationships between collection system, delivery size and season and somatic cells level count in raw milk classified to the highest quality classes]. Zesz. Nauk. Prz. Hod. 68(1), 115-119. [in Polish]

Radkowska I. 2013. Skład chemiczny oraz zawartość komórek somatycznych i mocznika w mleku krów w zależności od system utrzymania [Chemical composition, somatic cell count and urea content of cow milk depending on the housing system]. Rocz. Nauk. Zootech. 39(2), 295-305. [in Polish]

Sharma N., Simgh N.K., Bhadwal M.S. 2011. Relationship of somatic cell count and mastitis: an overview. Asian-Aust. J. Anim. Sci. 24(3), 429-438.

Simianer H., Solbu H., Schaeffer L.R. 1991. Estimated genetic correlations between disease and yield traits in dairy cattle. J. Dairy Sci. 74, 4358-4365.

Skrzypek R. 2006. Factors affecting somatic cel count and total microorganisms count in cow's milk. Pol. J. Food Nutr. Sci. 56(15), 1, 209-213.

Smith G. 2003. Dairy processing, improving quality. Cambridge Woodhead Publishing, England, 185-207.

Stanek P., Litwińczuk Z., Teter U., Jankowski P. 2004. Skład chemiczny mleka krów czarno-białych utrzymywanych w gospodarstwach farmerskich Lubelszczyzny, z uwzględnieniem pory roku i ich dziennej produkcyjności [Chemical composition and cytological quality of milk from Black - and White cows kept on the farm Lubelszczyzna with regard to season and daily productivity]. Zesz. Nauk. Prz. Hod. PTZ 72(1), 153-159. [in Polish]

Wójcik J., Kamieniecki H., Sablik P., Czajkowska T. 1998. Analiza skupu mleka surowego na przykładzie wybranych zakładów mleczarskich. Nowe technologie żywienia i utrzymania przeżuwaczy poprawiające efektywność ich produkcji. Szczecin, AR, 19-25. [in Polish]

Wójcik J., Kamieniecki H., Sablik P., Szarkowski K., Lachowski W. 1997. Tendencje w skupie mleka na Pomorzu Zachodnim po fazie przekształceń własnościowych. Chów bydła w warunkach konkurencyjnej gospodarki rynkowej. Szczecin, AR, 89-94. [in Polish] 
Abstract. The purpose of the conducted studies was the assessment of the quality of raw milk purchased by the dairy plant, including the purchase volume, the quality of the raw milk and the seasonality of its purchase. Farms were divided by the amount of milk produced: 1 group to $5000 \mathrm{~kg}$ of milk per month; 2 groups $5001-10000 \mathrm{~kg}$ of milk; 3 groups of 10001 to 15000 milk per month; 4 group over $15000 \mathrm{~kg}$ of milk per month. A slightly higher percentage of fat in milk from group 4 was found. The microbiological purity of milk was similar in all groups, highlighting the small LKS and OLB. The existing seasonality of production has been observed. The production volume during the summer period was about $18 \%$ higher. It seems appropriate to continue to specialize farms and introduce in the bigger farms the full-year feeding system (TMR). 
